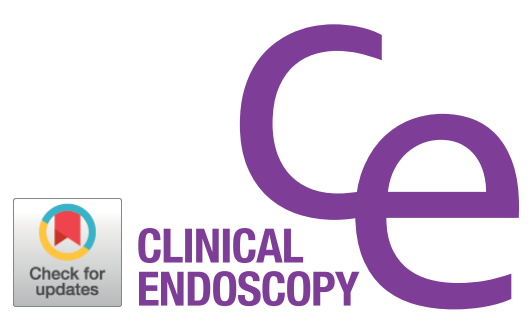

\title{
Differential Diagnosis for Chronic Diarrhea: Are Multiple Random Biopsies with Colonoscopy Mandatory?
}

\section{Shin Hee Lee and Sang-Bum Kang}

Division of Gastroenterology, Department of Internal Medicine, Daejeon St. Mary's Hospital, College of Medicine, The Catholic University of Korea, Daejeon, Korea

\section{Quiz}

A 65-year-old woman visited our hospital complaining of watery diarrhea and intermittent low abdominal pain for the past 6 months. Her stool frequency was generally $5-10$ times a day. Her symptoms did not include fever, weight loss, rectal bleeding, or bowel movements at night. Colonoscopy 6 months ago were not remarkable. She takes aceclofenac for knee pain as needed.
Her complete blood count, blood chemistry, and thyroid function analysis were normal. Results of stool examination, including toxin for Clostridium difficile, were negative, except for a slightly elevated fecal calprotectin level $(110 \mu \mathrm{g} / \mathrm{mg})$. Colonoscopy was performed to identify the cause of chronic diarrhea. The colonic mucosa was relatively normal, but the vascular pattern sporadically decreased (Fig. 1). Multiple random biopsies were performed in the entire colon (Fig. 2).

What is the most likely diagnosis?
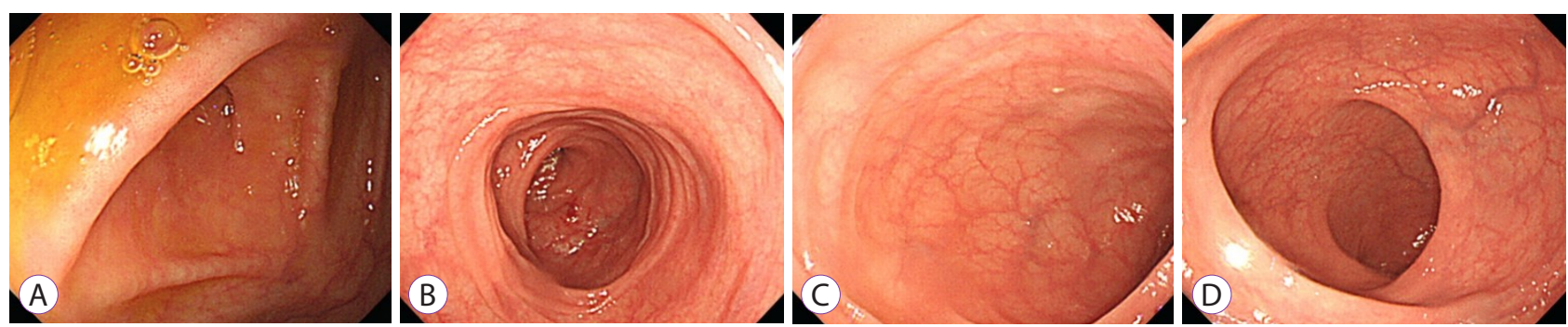

Fig. 1. Colonoscopic findings demonstrating a relatively normal colonic mucosa with some areas of decreased vascular pattern in the cecum (A), transverse colon (B), sigmoid colon (C), and rectum (D).
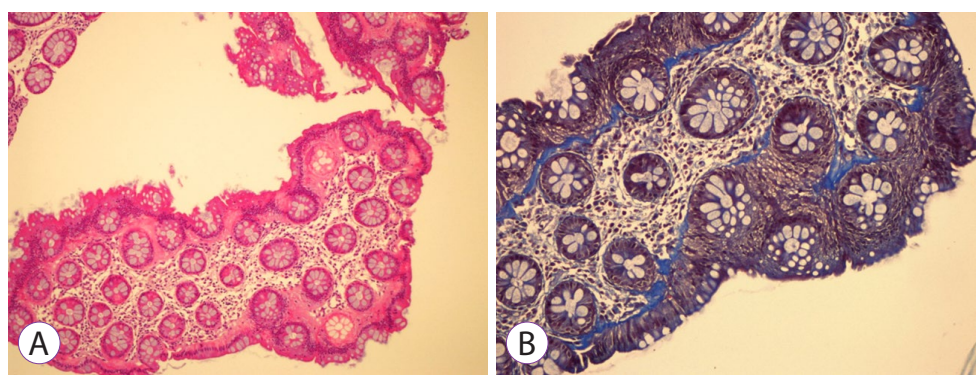

Fig. 2. Microscopic findings showing a thickened subepithelial collagen band $(12 \mu \mathrm{m})$ with $(\mathrm{A})$ hematoxylin and eosin stain, $\times 50$ magnification, and (B) Masson's Trichrome stain, $\times 100$ magnification.

Received: December 23, 2020 Revised: January 12, 2021

Accepted: January 14, 2021

Correspondence: Sang-Bum Kang

Division of Gastroenterology, Department of Internal Medicine, Daejeon St. Mary's Hospital, College of Medicine, The Catholic University of Korea, 64 Daeheung-ro, Junggu, Daejeon 34943, Korea

Tel: +82-42-220-9501, Fax: +82-42-252-6807, E-mail: dxandtx@catholic.ac.kr

ORCID: https://orcid.org/0000-0002-1946-7896

(cc) This is an Open Access article distributed under the terms of the Creative Commons Attribution Non-Commercial License (http://creativecommons.org/licenses/by$\mathrm{nc} / 3.0$ ) which permits unrestricted non-commercial use, distribution, and reproduction in any medium, provided the original work is properly cited. 


\section{Answer}

Based on the pathological findings, the diagnosis was collagenous colitis (CC), a subtype of microscopic colitis (MC). $\mathrm{MC}$ is a relatively common cause of chronic and intermittent, watery, non-bloody diarrhea, especially in women and elderly individuals. ${ }^{1}$ Other symptoms may include abdominal pain, weight loss, urgency, fecal incontinence, fatigue, arthralgia, and myalgia. Diabetes, thyroid dysfunction, and psoriasis are more common in patients with MC. Studies have reported on the association of MC with several medications, such as non-steroidal anti-inflammatory drugs, proton pump inhibitors, aspirin, acarbose, selective serotonin reuptake inhibitors, and ticlopidine. ${ }^{2}$

Colonoscopic findings are usually normal, even in cases of minor colonic mucosal changes such as erythema, edema, and abnormal vascular pattern. Occasionally, colonic mucosal tears (cat-scratch colon) may also be observed. ${ }^{3}$ Multiple random biopsies are essential for differential diagnosis, considering that the majority of the presenting symptoms are non-specific and it is difficult to distinguish them from those of irritable bowel syndrome. The two most typical forms of MC are CC and lymphocytic colitis (LC). The characteristic histopathological finding of CC is a subepithelial collagen band $\geq 10 \mu \mathrm{m}$ in thickness. The diagnosis of LC depends on the presence of an increased number of intraepithelial lymphocytes (IELs), for example, over 20 IELs per 100 epithelial cells. Fecal calprotectin is generally slightly elevated. ${ }^{4}$
Antidiarrheal medications such as loperamide, diphenoxylate, mesalamine, budesonide, azathioprine, and tumor necrosis factor-alpha inhibitors can be effective in the treatment of patients with MC. ${ }^{5}$ Therefore multiple random biopsies should be performed to evaluate the cause of chronic diarrhea.

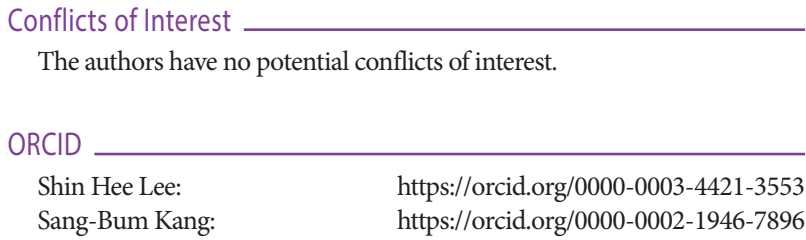

\section{REFERENCES}

1. Mellander MR, Ekbom A, Hultcrantz R, Löfberg R, Öst Å, Björk J. Microscopic colitis: a descriptive clinical cohort study of 795 patients with collagenous and lymphocytic colitis. Scand J Gastroenterol 2016;51:556562 .

2. von Arnim U, Wex T, Ganzert C, Schulz C, Malfertheiner P. Fecal calprotectin: a marker for clinical differentiation of microscopic colitis and irritable bowel syndrome. Clin Exp Gastroenterol 2016;9:97-103.

3. Park T, Cave D, Marshall C. Microscopic colitis: a review of etiology, treatment and refractory disease. World J Gastroenterol 2015;21:88048810.

4. Pardi DS. Diagnosis and management of microscopic colitis. Am J Gastroenterol 2017;112:78-85.

5. Miehlke S, Verhaegh B, Tontini GE, Madisch A, Langner C, Münch A Microscopic colitis: pathophysiology and clinical management. Lancet Gastroenterol Hepatol 2019;4:305-314. 